\title{
Treatment of initial allergic reactions to peanut inside and outside of health care facilities
}

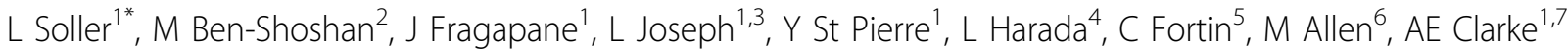 \\ From Canadian Society of Allergy and Clinical Immunology Annual Scientific Meeting 2009 \\ Halifax, Canada. 22-25 October 2009
}

\section{Background}

Recent studies suggest increased admission rates for food-related anaphylaxis. The only effective treatment for anaphylaxis is prompt administration of epinephrine.

\section{Objectives}

To characterize treatment practices of initial allergic reactions inside and outside health care facilities (HCF).

\section{Methods}

Individuals with an allergist-confirmed peanut allergy were recruited from the Montreal's Children Hospital and Canadian food allergy advocacy organizations. Data were collected on initial allergic reactions to peanut and treatment inside and outside HCFs.

\section{Results}

Of 751 individuals who had an allergic reaction to peanut, 613 responded (81.6\%). Initial reactions were mild in $28.4 \%$ (95\% CI, $25.0-32.1 \%$ ), moderate in $50.6 \%$ (46.6$54.6 \%$ ), and severe in $20.9 \%$ (17.8-24.3\%). Average age of initial reaction was 2.1 years (2.0-2.3). Among participants, $11.6 \%$ (9.1-14.7\%) were diagnosed with peanut allergy (based on skin and IgE testing) prior to the initial reaction. Of the 613 participants, $32.1 \%$ (28.5-36.0\%) were treated in HCFs only, 51.7\% (47.7-55.7) outside HCFs only, and 16.2\% (13.4-19.3\%) in both. $21.3 \%$ (17.0$26.3 \%)$ of all reactions treated in HCFs received epinephrine (table) versus only $3 \%(1.8-5.1 \%)$ treated outside. Of those with moderate or severe initial reactions, $58.2 \%$ (53.5-62.8\%) were treated in HCFs, and 23.9\% (19.1-29.6\%) of these received epinephrine. See table 1.

Table 1

\begin{tabular}{|c|c|c|c|c|c|c|}
\hline & \multicolumn{3}{|c|}{$\%$ of Respondents Receiving each Treatment in HCF } & \multicolumn{3}{|c|}{$\begin{array}{l}\% \text { of Respondents Receiving each Treatment outside } \\
\text { HCF }\end{array}$} \\
\hline & $\begin{array}{l}\text { Epinephrine }+/- \\
\text { other medications\% } \\
(95 \% \mathrm{Cl})\end{array}$ & $\begin{array}{l}\text { Other medications } \\
\text { (excluding } \\
\text { epinephrine) }\end{array}$ & None & $\begin{array}{l}\text { Epinephrine +/- } \\
\text { other } \\
\text { medications }\end{array}$ & $\begin{array}{l}\text { Other medications } \\
\text { (excluding } \\
\text { epinephrine) }\end{array}$ & None \\
\hline All reactions & $21.3(17.0-26.3)$ & $50.7(45.0-56.4)$ & $28.0(23.2-33.5)$ & $3.0(1.8-5.1)$ & $47.2(42.6-51.8)$ & $49.8(45.2-54.4)$ \\
\hline \multicolumn{7}{|l|}{ Severity } \\
\hline Mild & $4.9(1.5-16.2)$ & $39.0(25.6-54.4)$ & $56.1(40.1-70.2)$ & $0.0(0.0-2.6)$ & $50.4(41.1-58.5)$ & $49.6(41.5-57.8)$ \\
\hline Moderate & $15.1(10.4-21.5)$ & $54.1(46.3-61.7)$ & $30.8(24.1-38-4)$ & $4.3(2.3-7.8)$ & $46.8(40.4-53.2)$ & $48.9(42.5-55.4)$ \\
\hline Severe & $38.5(29.4-48.6)$ & $50.0(40.1-59.9)$ & $11.5(6.5-19.4)$ & $4.5(1.8-11.2)$ & $43.2(33.3-53.7)$ & $52.3(41.9-62.5)$ \\
\hline \multicolumn{7}{|c|}{$\begin{array}{l}\text { Peanut allergy } \\
\text { diagnosed prior to } \\
\text { reaction }\end{array}$} \\
\hline Yes & $17.2(7.7-34.8)$ & $48.3(31.3-65.7)$ & $34.5(20.0-52.9)$ & $6.5(2.3-17.6)$ & $67.4(52.8-79.2)$ & $26.1(15.6-40.4)$ \\
\hline No & $20.9(16.0-26.8)$ & $53.6(47.0-60.2)$ & $25.5(20.1-31.6)$ & $2.7(1.4-5.0)$ & $44.7(39.4-50.0)$ & $\mathbf{5 2 . 6}(47.3-58.0)$ \\
\hline
\end{tabular}

'Division of Clinical Epidemiology, Department of Medicine, McGill University

Health Center, Canada 


\section{Conclusion}

Almost $50 \%$ of individuals with potentially life-threatening initial reactions are not treated in HCFs. Further, for those with moderate and severe reactions treated in HCFs, there is substantial underuse of epinephrine. Thus, it is crucial to establish, distribute, and monitor treatment guidelines that would improve treatment practices of food-related allergic reactions.

\section{Author details}

'Division of Clinical Epidemiology, Department of Medicine, McGill University Health Center, Canada . ${ }^{2}$ Division of Pediatric Allergy and Clinical Immunology, Department of Pediatrics, McGill University Health Center, Montreal, Quebec, Canada . ${ }^{3}$ Departments of Epidemiology and Biostatistics, McGill University, Canada . ${ }^{4}$ Anaphylaxis Canada (AC), Canada . ${ }^{5}$ Association Québécoise des Allergies Alimentaires (AQAA), Canada . ${ }^{6}$ Allergy/Asthma Information Association (AAIA), Canada. ${ }^{7}$ Division of Allergy and Clinical Immunology, Department of Medicine, McGill University Health Center, Canada

Published: 12 May 2010

doi:10.1186/1710-1492-6-S1-P31

Cite this article as: Soller et al: Treatment of initial allergic reactions to peanut inside and outside of health care facilities. Allergy, Asthma \&

Clinical Immunology 2010 6(Suppl 1):P31.

Submit your next manuscript to BioMed Central and take full advantage of:

- Convenient online submission

- Thorough peer review

- No space constraints or color figure charges

- Immediate publication on acceptance

- Inclusion in PubMed, CAS, Scopus and Google Scholar

- Research which is freely available for redistribution

Submit your manuscript at www.biomedcentral.com/submit 